ずれかを donor とするが，両者とも interposition graft 要す る。これには流量の多い静脈片あるいは人工血管を用いる.

椎骨動脈起始部の狭窄性病変に対しては, 起始部の頸動脈 あるいは鎖骨下動脈への転移術が適応となるが，遮断による 脳虚血の予防の観点からは後者が推奨される。この術式は, 開胸を必要とせず鎖骨上からアプローチでき，また長期的に も再狭窄がほとんど出現しないという利点がある。椎骨動脈 起始部の閉塞があるものの側副血行を介して順行性に頸部椎 骨動脈が造影される病変に対しては，「血行再建術は中枢側 から」の原則に基づき静脈片を interposition graft とする外頸 動脈一椎骨動脈のバイパスを行う。椎骨動脈側は最も中枢側 の内腔の開いている部位の横突孔を開放し, recipientを確保 する，いずれの手術も術野はやや狭いが，顕微鏡下で十分な 視野をとることが可能である。

\section{8. 頭蓋外椎骨，鎖骨下動脈狭窄症に対する血管内 治療}

和歌山県立医科大学脳神経外科 寺田 友昭, 津浦 光晴, 板倉

頭蓋外椎骨動脈，鎖骨下動脈に対する血管内治療は，手技 に伴う血栓塞检性合併症の低さ，アプローチの容易さより， 比較的早期から治療の行われてきた分野である.

これらの血管内治療の適応は, 椎骨動脈狭窄では, 原則と して症候性の $60 \%$ 以上のもの，鎖骨下動脈では症候性また は血圧の左右差 $20 \mathrm{mmHg}$ 以上の $70 \%$ 以上の狭窄を有するも のとしている，方法は，椎骨動脈狭窄は原則として血管形成 術（PTA）を行い, 拡長不十分なものや解離の生じたもの, 再狭窄例にはステント留置を行っている、ステントはバルー ン拡長型のもの（冠動脈用のものやPalmaz）を用い，一部 断端が鎖骨下動脈に突出するように留置する。鎖骨下動脈狭 窄（閉塞を含む）は primary stentingを行うことが多いが, 椎骨動脈を含むような場合は kissing balloon techniqueを用い たPTAで終了することもある，ステントは自己拡長型，バ ルーン拡長型のものが使用可能であるが, ostial lesionのも のはバルーン拡長型を用いる.アプローチは鼠径, 上腕両方 から可能であるが, 最近では両側からのアプローチを行って いる。また，両病変に対しては原則として protection techniqueは用いていない.

現在まで, 鎖骨下動脈狭窄 16 病変 (2例は完全閉塞), 椎 骨動脈狭窄 27 例， 32 病変に対して血管内治療を行った．椎 骨動脈ではPTA群で 77\%-33\%, stent 群で 74\%-10\%まで 狭窄率が改善した。鎖骨下動脈ではPTA群で 73\%-23\%, ステント群で $87 \%-6 \%$ であり，ともにステント群で拡張は 良好であった。椎骨動脈狭窄群でTIAを 1 例に認めたが, morbi/mortalityは0であった。

以上, 本病変の診断, 治療について概説する。

\section{9、動脈硬化と再狭窄の病理}

国立循環器病センター臨床検査部・病理 由谷 親夫

1. 動脈硬化症の病理 : 動脈硬化症とは, 動脈系にみられ る一連の細胞性反応である。 その反応は解剖学的局在性, 年 㱓, 性, 個体が受ける危険因子などの影響を受け, 多彩な形 をとる. 最近の免疫学や分子生物学の進歩により, 動脈硬化 の病変に関与する細胞相互間の応答反応が解明されるに従 い，炎症反応としてとらえる方向性が示されつつある．臨床 的にもっとも重要である粥状硬化症を中心に述べる.

2. 冠状動脈硬化症: 最近の血管内視鏡や血管内エコーは, 硬化斑の表面性状まで読みとることが可能になり，硬化斑の 病態把握が重要になってくると，とても従来の分類では間に あわなくなってきた。 こうした時代背景もあって，1995年 AHA 委員会から冠状動脈硬化症を中心にした新しい分類が 提唱された。

3. 急性冠症候群 (ACS) とコロナリーインターベンショ ン: 冠状動脈血栓症の発生において, 狭窄や進展や閉塞に至 る過程で籿腫の破綻が重要である。粇腫破綻に引き続いて起 こる血栓形成が, ACSの発症に密接に関与している. 最近, 循環器領域で臨床応用の著しいインターベンションは, その 基礎病態に粥腫破綻があり，それによる再狭窄も十分あり得 るのである。

（1）PICA後再狭窄の機序：PICAによる経時的変化をみ ると, プラーク破䋎部に一致して血栓形成が起こり, 中膜 平滑筋細胞の遊走，増殖の結果新生内膜が完成する.この ことと同時に外膜にも出血, 細胞浸潤が起こり線維化とな り，外膜からの慢性収縮による再狭窄が重要な機序と考え られる。

（2）ステント装着後再狭窄の機序：コロナリーステント 装着後再狭窄は, 約 $20 \%$ に発生し，新たな問題を提起し た、下肢動脈や頸動脈ステントのような血管径の比較的大 きな血管へのステントによる再狭窄が，血栓形成によると 考えられているのに反して，小口径の冠状動脈に置かれた ステントの場合, 一体何が起こるのだらうか

4. 再狭窄は予防できるか：新生内膜増殖, 血管りモデリ ング，血检形成，血管壁内圧の増加，ステントのデザインの 問題，炎症性肉芽反応，種々の原因が考光られているが，こ れらを予防することは可能であろうか？

5. 頸動脈内膜切除標本から見た動脈硬化の病理：このこ とについても少し触れたい.

\section{0. 動脈硬化と再狭窄の分子機構}

京都大学大学院医学研究科加㱓医学 久米 典昭

粥状動脈硬化, あるいは血管インターベンション後の再狭 